\title{
FERTILITY AND EMBRYO DEATH IN DOUBLE-YOLKED EGGS
}

\author{
N. S. FECHHEIMER AND W. P. JAFFE* \\ Department of Dairy Science and Poultry Science, \\ Ohio State University, Columbus, Ohio, U.S.A.
}

(Received 31st August 1965, revised 27th May 1966)

\begin{abstract}
Summary. The fertility of double-yolked chicken eggs was $42.9 \%$ of which $27 \%$ contained two embryos. Single and double embryos died at different times of incubation. Sex ratio at 14 days and later was $44 \%$ males $(P<0.02)$ for both types of embryo.
\end{abstract}

The occurrence of live twin embryos is rare in chicken eggs (Nalbandov, 1942; Jeffrey, Fox \& Smyth, 1953). Bernard's hen that laid ten double-yolked eggs from which eighteen chicks hatched out (Bernard, 1849) appears to be a unique performance. In Britain the first live twin chicks were reported in 1954 (Anon., 1954a). A pair of ducklings were reported in that year from the same part of the country (Anon., 1954b). However, such a rarity could be explained by the fact that commercial hatcheries do not usually set double-yolked eggs.

In her study of the development in double-yolked eggs, Monkman (1963) set 220 eggs of which fifty-three hatched. Seven of these were live twin pairs. From 500 double-yolked eggs incubated, Lutz \& Lutz-Ostertag (1959) studied sixteen pairs of twins of opposite sex alive at 14 days of incubation.

In conjunction with a series of experiments based upon opposite sexed twins, double-yolked chicken eggs were set. This paper contains data relative to the fertility, time and rate of embryo death and sex ratio of the embryos of doubleyolked eggs.

A total of 1414 eggs were set. Most of these were from commercial strains of layers, but a few were from broiler stocks. All eggs were candled at least once before the 16th day of incubation and those not showing the presence of two live embryos were opened. The fertility, and when possible, the age of death and sex of embryos were ascertained. Those eggs thought to contain two live embryos were opened at various times after the 16th day of incubation, and when possible the sex of embryos was determined.

The time of embryo death was placed into four categories: (1) death at 1 to 6 days of incubation; (2) 7 to 13 days, (3) 14 to 21 days, and (4) those that were alive when taken from the egg. The last category includes almost all of

* On leave from School of Veterinary Science, University of Bristol, England. 
category (3) had the embryos not been removed. Only three live chickens were obtained from 360 eggs incubated to term.

The overall fertility of 1414 eggs set was $42.9 \%$ (607 eggs had either one or two embryos). Time of death and sex ratio of these embryos are set out in Table 1. A feature of interest is that although the proportion of eggs with one and two dead embryos was approximately equal at 6 days, the proportion of single embryos dying between 7 and 13 days is five times as great as that of double embryos dying during this period. In contrast, one-third more double embryos survived after 14 days of incubation than did single embryos.

TABLE 1

NUMBERS OF FERTILE EGGS CONTAINING ONE OR TWO EMBRYOS WHEN OPENED

\begin{tabular}{|c|c|c|c|c|}
\hline \multirow{2}{*}{$\begin{array}{c}\text { No. of } \\
\text { embryos } \\
\text { in egg }\end{array}$} & \multicolumn{3}{|r|}{ Period of death of embryo (days) } & \multirow[b]{2}{*}{ Totals } \\
\hline & 1 to 6 & 4 to 13 & $\begin{array}{l}\text { Alive when } \\
\text { opened }\end{array}$ & \\
\hline 1 & $\begin{array}{l}135 \\
30 \cdot 5 \%\end{array}$ & $\begin{array}{l}85(9 ð, 10 \%) \\
19.2 \%\end{array}$ & $65(32 \delta, 33 \%) \quad 50.3 \%$ & $\begin{array}{l}443 \\
73 \%\end{array}$ \\
\hline 2 & $\begin{array}{l}44 \\
28 \cdot 0 \%\end{array}$ & $\begin{array}{l}6\left(1 \delta^{*}\right) \\
3 \cdot 8 \%\end{array}$ & 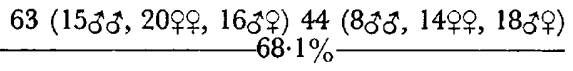 & $\begin{array}{l}164 * \\
27 \%\end{array}$ \\
\hline Total & & & & 607 \\
\hline
\end{tabular}

* Including seven eggs, not listed, because the two embryos contained in each died at different times during incubation.

The sex ratio of embryos alive at 14 days and later was $44 \%$ males in both single and double embryo eggs. As the ratios in the two classes were not significantly different, they were combined and found to differ significantly from the expected $1: 1$ ratio $(P<0.02)$. The homogeneity of the ratios in the two classes suggests that the altered sex ratios observed during the last third of incubation result from the presence of two yolks rather than from the number of embryos.

With a fertility of $43 \%$, of which $27 \%$ contain twin embryos, $11.6 \%$ of double-yolked eggs set had two embryos, two-thirds of these survived to 14 days or later. Of the twins surviving to 14 days, $62.6 \%$ were of like sex and $37.3 \%$ were unlike sexed. This deviation from the expected $1: 1$ ratio of like to unlike sexed twins approaches significance at the $5 \%$ level $\left(\chi^{2}=3 \cdot 76\right.$, one degree of freedom). The excess of like sexed twins appears to be due to a greater number of female pairs, in accordance with the observation on single embryos in which an excess of females was observed in the last stage of development.

\section{REFERENCES}

Anon. (1954a) Twin chicks hatched alive from one egg. Fmr $\hat{G}^{\circ}$ Stk-Breed. Northern Edition, p. 5. ANon. (1954b) Twin ducklings hatched from one egg. Fmr E Stk-Breed. Northern Edition, p. 107. Bernard, Glaude (1849) Discussion on 'Anomalie d'oeuf de poule'. C. r. Séanc. Soc. Biol. 1, 9.

Jefrexy, F. P., Fox, T. W. \& Smyrh, J. R., JR. (1953) Observations on double-yolked eggs from the domestic fowl. F. Hered. 44, 213.

Lutz, H. \& Lutz-Ostertag, Y. (1959) Free-martinisme spontane chez les oiseaux. Devl Biol. 1, 364. Monkman, M. (1963) A study of the development in double-yolked eggs. Thesis, University of Northen Illinois. Nalbandov, A. (1942) A case of viable twin chicks. F. Hered. 33, 53. 